Japanese science journals Nature bites the dust

\section{Tokyo}

ONE of Japan's oldest science journals, which for the past few years has carried on its front cover both the Japanese title Shizen and its English translation Nature, is to suspend publication.

Since it was launched in 1947, Nature (Shizen) has provided a unique monthly forum for Japanese scientists from all disciplines to present their work, in Japanese, to a wide audience. The bulk of the journal is made up of a section containing articles very much in the style of Nature's News and Views. The latest (and last) issue for April takes up themes ranging from grand unified theories to the twinkling of stars. Other sections provide a brief round-up of works appearing in foreign journals, many from Nature, and some longer and more technical articles under the heading Ronbun (theses).

The suspension of Nature (Shizen) by its publisher, Chuo Koron, has astonished many of Japan's scientists. Several factors seem to be responsible. In the now intense competition for the popular science readership, Nature (Shizen)'s circulation has been on the decline. Within the past three years, six new monthly science magazines, all of them illustrated with a lavishness that made Nature (Shizen)'s sober print look archaic, had acquired a combined circulation of 750,000 . This "science boom", reflecting, as Nature had hopefully speculate (see Nature 305, 365; 1983), a new pride in Japan's technological achievements, seems to have been short-lived.

Circulation of the new breed of sciencebased magazines has slumped this year and one of them is going out of business. The lack of interest in science is even persuading the promoters of Expo ' 85 - the giant international science exposition due to be held in Tsukuba Science City next year to push the sub-theme of "colour and image" rather than the basic theme of science and technology as it is "not a popular drawing card".

A further good reason for suspending publication of Nature (Shizen) came with the retirement of the editor, Akihiko Okabe, who had been running the journal for 32 years. During his long editorship Okobe has achieved something of a godlike status among Japanese scientists, and it is said that there were great difficulties in thinking of anyone who could succeed him in the post.

There is also, of course, the strange coincidence that Nature (Shizen)'s death comes just as Nature sets up its first Japanese office in Tokyo. Perhaps as one scientist at editor Okabe's farewell party put it, "it would be unnatural for a nation to have two natures".

Alun Anderson

Bulgaria

\title{
Computer industry goes soft
}

BULGARIA'S computer industry has been let down by the software sector, Ognyan Doinov, Minister of Machine Building, told the national conference of the Bulgarian Communist Party last month. Although computers similar to the Bulgarian models have elsewhere become a " powerful tool for mastering scientific and technical achievements", in Bulgaria, computers remain "dead objects" for lack of programming knowhow.

The conference was debating a new drive for "quality" in all aspects of the national economy which, Doinov said, could be achieved only by widespread modernization and automation of industry, development of indigenous technology to replace costly and often obsolescent imports and a campaign to make the whole nation computer-minded.

To begin with, training will concentrate on secondary-school and university students, whose education is already sub-

\section{Technology by bus}

BritaIN's Minister for Information Technology, Mr Kenneth Baker, announced last week the latest in his department's seemingly unending series of special schemes to promote applications of new technology. The department, together with the Manpower Services Commission, is to spend $£ 2.5$ million on setting up a national centre to train teachers technology.

The Department of Trade and Industry sees education as an important part of its activities; for example, it was behind the project, generally regarded as a success, to provide a microcomputer in every school in Britain. Its latest scheme might seem even more obviously to be trespassing on the patch of the Department of Education and Science, but Mr Baker seems to have more success in securing finance for innovative schemes than Sir Keith Joseph, Secretary of State for Education and Science. The new centre will eventually have to be self- stantially job orientated. The programme will centre on Bulgaria's new "'Pravets-82", personal computer, which goes into serial production this year and which, given appropriate programs, is expected to have a wide range of commercial, administrative and educational uses as well as becoming the basis for automatic quality control systems in industry.

The sociological implications of computer training have not been overlooked. Young people who fail to become familiar with computer techniques, Doinov said, will be unable to develop their talents and they will be "disappointed with both themselves and society", while those who master computer skills will be "satisfied and self-reliant". He even hinted that computers can be used for recreational purposes, thereby becoming probably the first Comecon minister to mention computer games in the august atmosphere of a party conference.

Vera Rich

\section{financing.}

The new British School Technology Centre has been developed from a teacher training project devised at Trent Polytechnic, in Nottingham. The success of the project in Bedfordshire, where it was first tried out, has persuaded the department that it would be worth promoting at a national level. Britain is very short of technology teachers and the new centre aims to educate and inspire by means of a travelling roadshow of buses equipped with all manner of miniature technological marvels. The buses will travel around Britain providing in-service training to teachers, while the new centre continues to develop its series of courses in technology education to promote to local education authorities. Many authorities are said to be showing interest, and in areas where the new courses have been used the number of pupils choosing to study technological subjects has increased dramatically.

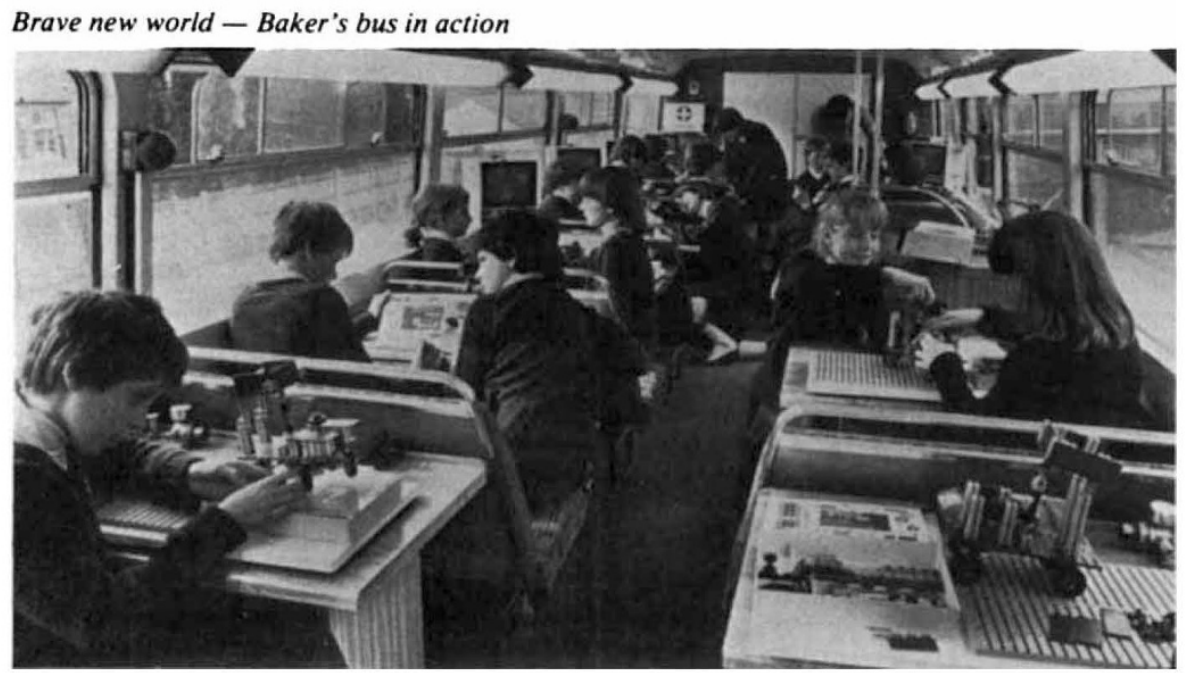

